\title{
Tavuk eti marinasyonunda ardıç (Juniperus communis L.) ekstraktı kullanımının etkilerinin araştırılması
}

\author{
Investigation of the effects of using juniper extract (Juniperus communis L.) in \\ marination of chicken meat
}

\author{
Hülya Serpil KAVUŞAN ${ }^{1}$ iD, Burcu ÖZTÜRK KERIMOĞLU² ${ }^{\text {iD }}$, Elnaz SHAREFIABADi ${ }^{\text {ID }}$, \\ Meltem SERDAROĞLU4*iD
}

1,2,3,4 Ege Üniversitesi Mühendislik Fakültesi Gıda Mühendisliği Bölümü, Bornova, İzmir, Türkiye

${ }^{1}$ https://orcid.org/0000-0003-2928-8020; ${ }^{2 h t t p s: / / o r c i d . o r g / 0000-0001-9777-8510 ; ~}{ }^{3}$ https://orcid.org/0000-0002-4382-0469;

${ }^{4}$ https://orcid.org/0000-0003-1589-971X

\section{To cite this article:}

Kavuşan, H.S., Öztürk Kerimoğlu, B., Sharefiabadi, E. \& Serdaroğlu, M. (2021). Tavuk eti marinasyonunda ardıç (Juniperus communis L.) ekstraktı kullanımının etkilerinin araştırılması. Harran Tarım ve Gıda Bilimleri Dergisi, 25(3): 390405.

DOI: 10.29050/harranziraat.863985

*Address for Correspondence: Meltem SERDAROĞLU e-mail:

meltem.serdaroglu@ege.edu.tr

Received Date:

18.01.2021

Accepted Date:

05.08.2021

(c) Copyright 2018 by Harran University Faculty of Agriculture. Available on-line at www.dergipark.gov.tr/harranziraat öz

Bu çalışmada enjeksiyon yöntemi ile marine edilen tavuk göğüs kaslarının marinasyon çözeltisi formülasyonunda \%0 (C), \%0.5 (A-0.5), \%0.75 (A-0.75) ve \%1 (A-1) oranlarında ardıç ekstraktı (AE) kullanımının bazı kalite parametreleri ve depolama boyunca lipit oksidasyonu üzerine etkileri incelenmiştir. Enjeksiyon yöntemi ile marine edilen taze tavuk göğüs etleri $+4^{\circ} \mathrm{C}^{\prime}$ de 24 saat bekletilmiş ve vakum ambalajlanarak $+4^{\circ} \mathrm{C}^{\prime}$ de 14 gün boyunca depolanmıştır. $A E$ ekstraktının kullanımının \%0.5 oranının üzerine çıkması göğüs etlerinin marinasyon absorpsiyonu ve su tutma kapasitesi değerlerini düşürmüştür $(p<0.05)$. AE ilavesi örneklerin nem, protein ve yağ miktarlarında önemli değişikliklere neden olmamıştır. Depolama süresi ve/veya antioksidan kullanım oranı interaksiyonunun $\mathrm{pH}$ değeri üzerindeki etkisi önemli bulunmuştur $(\mathrm{p}<0.05)$. AE ilavesi tavuk göğüs etinde oksidasyon reaksiyonlarını yavaşlatıcı etki göstermiştir; ancak depolamanın 7. gününden itibaren $\% 0.5^{\prime}$ ten fazla AE kullanımı prooksidan etki göstererek TBARS değerlerini yükseltmiştir $(p<0.05)$. AE kullanımının renk üzerindeki en belirgin etkisi örneklerin sarılık değerlerinde gözlenmiştir. Depolama süresi ve \%1 AE kullanımı ambalaja sızıntı değerlerinde artışa neden olmuştur $(p<0.05)$.

Anahtar Kelimeler: Ardıç, marinasyon, Lipit oksidasyonu, Doğal antioksidan, Kanatı hayvan eti

\section{ABSTRACT}

In this study, the use of juniper extract (JE) at rates of $0 \%(C), 0.5 \%(A-0.5), 0.75 \%(A-0.75)$, and $1 \%(A-1)$ on some quality parameters and lipid oxidation throughout the storage were examined in chicken breast muscles marinated by injection method. Marinated chicken breasts were kept at $+4{ }^{\circ} \mathrm{C}$ for $24 \mathrm{~h}$, packed under vacuum, and then stored at $+4^{\circ} \mathrm{C}$ for 14 days. The use of JE more than $0.5 \%$ decreased marination absorption and water holding capacity of the breast meat $(p<0.05)$. The addition of JE did not cause any significant changes in moisture, protein and fat content of the samples. The effect of storage time and/or antioxidant rate interaction on $\mathrm{pH}$ value was found to be significant $(\mathrm{p}<0.05)$. The addition of JE showed a deceleration effect on the oxidation reaction in chicken breast, however, the use of JE more than $0.5 \%$ increased the TBARS values showing a prooxidant effect after the $7^{\text {th }}$ day of storage $(p<0.05)$. The most significant effect of the incorporation of JE on color was observed in the yellowness values of the samples. Storage time and use of $1 \%$ JE resulted in an increase in purge losses $(p<0.05)$.

Key Words: Juniper, Marination, Lipid oxidation, Natural antioxidant, Poultry meat 
Giriş

Spor yapan veya düşük enerjili diyetle beslenmek isteyen bireyler; yüksek protein kalitesi, uygun fiyatı, kırmızı ete oranla daha düşük miktarlarda yağ ve daha sağlıklı bir yağ asidi profili içermesi nedeniyle tavuk eti tüketimini tercih etmektedirler (Brenes ve Roura, 2010; De Smet, 2012). Bu doğrultuda, günümüzde kanatlı endüstrisi, artan tüketim talebine katkı sağlamak amacıyla kalite özellikleri farklı yöntemler kullanılarak geliştirilmiş ürünlerin üretimi ile ilgili çalışmalara odaklanmıştır (OECD/FAO, 2016).

Doymamış yağ asitlerini yüksek oranda bulunduran kanatlı eti ürünlerinde acılaşma, istenmeyen koku ve tat oluşumu ve renkte solma ile karakterize edilen bozulmanın başlıca nedeni lipitlerde meydana gelen ve raf ömrünü kısıtlayan oksidasyon reaksiyonlarıdır (Falowo ve ark., 2014; Candan ve Bağdatlı, 2017). Kaliteyi olumsuz yönde etkileyen bu tepkimeler sonucunda toksik bileşiklerin de oluşması, oksidasyon reaksiyonlarının önlenmesi ve/veya geciktirilmesi gerekliliğini ön plana çıkarmaktadır (Amaral ve ark., 2018). Bu amaçla, peroksit zincir reaksiyonlarını engelleme, serbest radikalleri yakalama ve stabilize etme yeteneği gösteren bazı yapay antioksidanlar (bütillenmiş hidroksi anisol, bütillenmiş hidroksi toluen, tersiyer bütil hidrokinon, propil gallatlar, vb.) yağlar ve yağlı gıdaların formülasyonlarında kullanılmaktadır (Çelik ve ark., 2021). Ancak sentetik antioksidanlar, potansiyel toksik etkileri nedeniyle sağlık riskleri ile ilişkilendirildiğinden bu tip antioksidanların gıdalarda kullanımları ile ilgili katı yasal düzenlemeler söz konusudur (Dolatabadi ve Kashanian, 2010; Mira-Sánchez ve ark., 2020). Doğal antioksidan özellikte olan bileşenler, karışım halinde hazırlanan et ürünlerinde formülasyona doğrudan ilave edilebilmekte (Banerjee ve ark., 2012; Cho ve ark., 2015; Munekata ve ark., 2020), bütün parça halindeki et ürünlerinde ise bu bileşenler genellikle marinasyon çözeltisi içerisine ilave edilerek kullanılmaktadır (Kim ve ark., 2016; Ramli ve ark., 2020; Siroli ve ark., 2020).
Marinasyon; et ve et ürünlerinin ısıl işlem öncesinde içerisinde fonksiyonel katkı maddeleri, baharatlar ve aroma vericilerin bulunduğu sıvilar ile muamele edilmesi işlemidir (Jeong ve ark., 2020). Farklı katkı maddeleri ile hazırlanan marinasyon çözeltilerinin etin içerisine daha hızlı nüfus etmesi amacıyla daldırma, çok iğneli enjeksiyon, masajlama veya tamburlama gibi çeşitli marinasyon yöntemleri kullanılmaktadır (Gamage ve ark., 2017; Gómez-Salazar ve ark., 2018; Singh ve ark., 2020). Enjeksiyon yöntemi, en yaygın kullanılan marinasyon yöntemlerinden biridir ve endüstriyel uygulamalarda marinasyon çözeltileri et parçalarına çoklu iğneler kullanılarak enjekte edilmektedir (Alvarado ve McKee, 2007; Fadıloğlu ve Serdaroğlu, 2018). Bu uygulamanın diğer yöntemlere kıyasla avantajı, marinasyon sıvısının kas içine istenilen miktarda homojen olarak uygulanabilmesidir; ancak büyük et parçaları ile çalışılan bu yöntemde sızıntı nedeniyle oluşan kayıpların kontrol edilmesi önemlidir (Ergezer ve Gökçe, 2004). Literatür verileri incelendiğinde; son yıllarda et marinasyonunda kekik, biberiye ve ardıç (Siroli ve ark., 2020), misket limonu ve kerkede bitkisi (Malelak ve ark., 2017), çarkıfelek meyvesi kabuğu (Ramli ve ark., 2020), yeşil çay (Suradi ve ark., 2019), muz kabuğu (Hafez ve ark., 2018), kivi ve ananas (Kim ve ark., 2016), hurma, çay ve mum ceviz ağacı (Ismail ve ark., 2018), timol ve karvakrol (Karam ve ark., 2019) gibi farklı doğal antioksidanların kullanımının ürün kalitesi üzerine etkilerinin incelendiği görülmektedir.

Ardıç (Juniperus communis L.), Kuzey Yarım Küre'de 70 kadar tür ve çok sayıda varyete ile geniş alanlarda yayılım göstermekte olan bir meyvedir ve Türkiye'de sekiz adet ardıç türü bulunmaktadır (Coşkun, 2019). Ardıç meyveleri; flavonoidler, glikozit, juniperin, kateşin, organik asitler, uçucu yağlar, terpenik asitler, lökoantosiyanidin lignanlar, kumarinler, seskiterpenler, abietan, labdan ve pimaran diterpenleri, biflavonoller, flavon glikozitleri ve taninleri içermektedir (Topçu ve ark., 1999; Inci ve ark., 2016). Kompozisyonunda bulunan fenolik bileşiklerin indirgeyici, metal şelatlayıcı ve/veya 
serbest radikal temizleyici etkileri ile ardıç meyvesi ekstraktları önemli antioksidan etkiye sahiptir (Elmastaş ve ark., 2006; Vasilijević ve ark., 2018). Ardıç ekstraktının (AE) bahsedilen bu kuvvetli antioksidan özelliklerine rağmen et marinasyonunda kullanımına yönelik bir çalışma daha önce gerçekleştirilmemiştir. Mevcut çalışmada tavuk göğüs etinde marinasyon formülasyonunda farklı oranlarda $A E$ kullanımın kalite özellikleri ve depolama boyunca oksidatif değişiklikler üzerine etkilerinin incelenmesi amaçlanmıştır.

\section{Materyal ve Metot}

\section{Hammadde ve kimyasal temini}

$\mathrm{Bu}$ çalışma, Ege Üniversitesi Mühendislik Fakültesi Gıda Mühendisliği Bölümü Et Teknolojisi Araştırma Laboratuvarları ve Pilot Tesisinde gerçekleştirilmiştir. Çalışmada kullanılan ölüm sertliğini tamamlamış 48 adet tavuk göğüs eti (\%75.43 nem, \%21.01 protein, \%1.91 yağ ve \%1.66 kül), İzmir ilinde bulunan yerel bir kasaptan sağlanmış ve $11 \mathrm{~cm} \times 3 \mathrm{~cm}$ boyutlarında şeritler halinde porsiyonlanmıştır. Suda çözünür sıvı $A E$, Kimbiotek Kimyevi Maddeler San. Tic. A.Ş. (İstanbul)'den temin edilmiştir. Üretici tarafından sağlanan ticari spesifikasyona göre, bu ekstrakt ardıç ağacının fermente olmamış meyvelerinden buhar destilasyonu yoluyla elde edilen, renksizaçık sarı skalada bir renk tonuna sahip, sıvı formda, suda çözünebilir özellikte, karakteristik ve taze aromaya sahip bir ekstrakttır (CAS no: 8460369-0). Marinasyon işleminde kullanılan diğer katkı maddeleri gıdada kullanılabilir formda (food grade) A\&D Kimya San. ve Tic. Ltd. Şti. (İstanbul)'dan satın alınmıştır. Analizler için tüm kimyasallar analitik saflıkta (Merck) kullanılmıştır.

\section{Marine tavuk göğüs üretimi}

Çalışma kapsamında; kontrol (K) grubu örnekleri için \%6 (a/h) tuz (sodyum klorür) ve \%3 (a/h) sodyum tripolifosfat (STPF) içeren içme suyu ile hazırlanan marinasyon çözeltisi Rimini ve ark. (2014)'a göre hazırlanmıştır. Marinasyon formülasyonunda tuz; arzu edilen lezzetin sağlanması, miyofibriler proteinlerin çözünerek suyun bünyede tutulmasının sağlanması ve etin gevrekleştirilmesi, STPF ise $\mathrm{pH}$ değerini izoelektrik noktadan uzaklaştırarak su tutma kapasitesinin arttırılması ve tuz ile birlikte protein çözünürlüğüne de katkı sağlamak amacıyla kullanılmıştır. Diğer örnek grupları için ise bu formülasyona ilaveten sırasıyla \%0.5 (a/a) (A-0.5), $\% 0.75$ (a/a) (A-0.75) ve \%1 (a/a) (A-1) oranında $A E$ ilave edilen marinasyon çözeltileri hazırlanmıştır. Gerçekleştirilen çalışmaya ait deneme deseni Şekil 1 'de sunulmuştur.

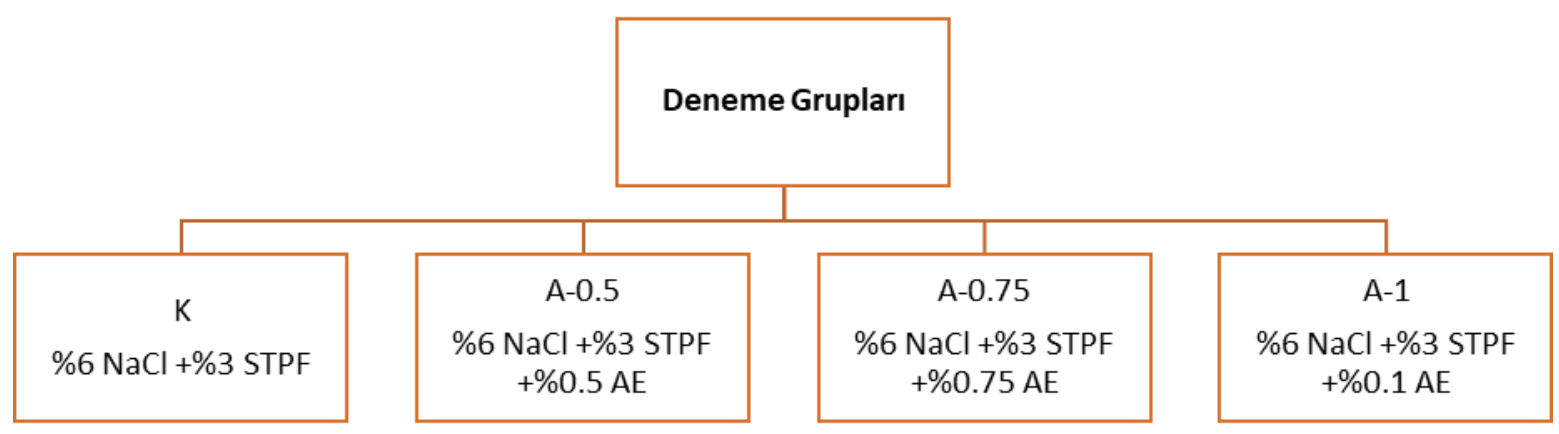

Şekil 1. Marine tavuk göğsü örneklerine ait deneme deseni $\mathrm{NaCl}$ : Sodyum klorür, STPF: Sodyum tripolifosfat, AE: Ardıç Ekstraktı Figure 1. Experimental design of marinated chicken breast samples NaCl: Sodium chloride, STPF: Sodium tripolyphosphate, AE: Juniper Extract

Hazırlanan marinasyon çözeltileri, tavuk göğüs porsiyonlarına $1.4 \mathrm{~mm}$ x $15 \mathrm{~mm}$ ebatlarında enjektör ucuna sahip enjektör (Mika, Türkiye) yardımıyla eşit aralıklara sahip üç farklı noktadan 1:1 (tavuk eti:marinasyon çözeltisi, a/h) oranında enjekte edilmiştir. Enjeksiyonu tamamlanan tavuk 
etleri polietilen kilitli poşetlerde $+4^{\circ} \mathrm{C}^{\prime}$ de 24 saat boyunca marinasyona bırakılmıştır. Süre sonunda marinasyon veriminin ölçülmesi amacıyla örnekler tartılmış ve ardından vakum altında ambalajlanarak (PA/PE, $90 \mu \mathrm{m}$, oksijen geçirgenliği: $\left.15 \mathrm{~cm}^{3} \mathrm{~m}^{-2} \mathrm{~d}^{-1} \mathrm{~atm}^{-1}\right)+4^{\circ} \mathrm{C}^{\prime}$ de 14 gün depolanmıştır.

\section{Marinasyon absorpsiyonu (MA)}

Marinasyon işleminin verimi, marinasyon öncesi ve marinasyon sonrası (24 saat) ölçülen tartım ağırıkları farklarından yararlanılarak hesaplanmıştır (Xiong ve ark., 2020).

\section{Kimyasal kompozisyon}

Marine tavuk göğüs örneklerinde kimyasal kompozisyonunun belirlenmesi amacıyla toplam nem (AOAC, 2012), protein (LECO nitrojen analizörü, St. Joseph, MI, $A B D$ ), yağ (Flynn ve Bramblet, 1975) ve kül (AOAC, 2012) analizleri gerçekleştirilmiştir.

pH

Örneklerin $\mathrm{pH}$ değerleri marinasyon sonrası (24. saat, 0. gün) ve depolamanın 3., 7. ve 14. günlerinde penetrasyon probu bulunan batırma tip $\mathrm{pH}$-metre (pH 330i/SET; WTW, Germany) kullanılarak ölçülmüştür.

\section{Su tutma kapasitesi (STK)}

STK tayini Hughes ve ark. (1997)'a göre uygulanmıştır. $10 \mathrm{~g}$ örnek tartılarak $90^{\circ} \mathrm{C}^{\prime}$ lik su banyosunda $10 \mathrm{dk}$. boyunca Isıl işleme tabi tutulmuş, ardından soğutularak pamuklu sargı bezine sarılıp $1400 \mathrm{rpm}$ 'de $15 \mathrm{dk}$. boyunca santrifüjlenmiştir. Santrifüjleme sonunda sargı bezi uzaklaştırılarak tekrar tartım alınmış ve STK aşağıdaki eşitlik yardımıyla hesaplanmıştır:

$$
\% S T K=(1-T / M) \times 100=(1-(B-A) / M) \times 100
$$

T: Isıtma ve santrifüjleme sonucu toplam su kaybı (g)

$B$ : Isıtma öncesi örnek ağırlığı (g)

A: Isıtma ve santrifüjleme sonrası örnek ağırlığı (g) M: Örnekteki toplam su (g)
Tiyobarbütirik asit reaktif maddeleri (TBARS) değeri

Deneme örneklerinde ve depolama boyunca lipit oksidasyonu son ürünlerini saptamak amacıyla TBARS analizi Witte ve ark.'a (1970) göre yapılmıştır. Buna göre, $20 \mathrm{~g}$ örnek üzerine $50 \mathrm{~mL}$ \%20'lik TCA çözeltisi ilave edilerek homojenizatörde $2 \mathrm{dk}$. süreyle parçalanmıştır. Karışım üzerine $50 \mathrm{~mL}$ su konularak $1 \mathrm{dk}$. daha parçalama işlemi yapılmış ve $100 \mathrm{~mL}$ 'lik balon jojeye filtre kâğıdı yardımıyla süzülmüştür. Balon joje $100 \mathrm{~mL}$ ye 1:1 TCA/su çözeltisi ile tamamlanmıştır. $5 \mathrm{~mL}$ süzüntü $100 \mathrm{~mL}$ 'lik balon jojeden alınıp deney tüpüne aktarıımış ve üzerine $5 \mathrm{~mL} 0.02$ M TBA çözeltisi ilave edilmiştir. Aynı şekilde $5 \mathrm{~mL}$ 1:1 TCA:su ve 0.02 M TBA ile kör numune hazırlanmıştır. Tüpler karıştırılmış, $35 \mathrm{dk}$. boyunca $80^{\circ} \mathrm{C}$ 'deki su banyosunda bekletilmiş ve soğutulduktan sonra örneklerin absorbansı 532 $\mathrm{nm}$ dalga boyuna ayarlanmış spektrofotometre ile ölçülmüştür. Absorbans değerleri 5.2 faktörü ile çarpılarak TBARS değeri $\mathrm{mg}$ malonaldehit/kg örnek cinsinden hesaplanmıştır.

\section{Renk}

Renk ölçümü portatif renk ölçüm cihazı (Konica Minolta, CR-400, Japonya) ile gerçekleştirilmiştir. Ölçümler oda sıcaklığında 4 farklı noktadan yapılmış, ölçüm sonuçları CIE aydınlık $\left(L^{*}\right)$, kırmızılık $\left(a^{*}\right)$ ve sarılık $\left(b^{*}\right)$ olarak ifade edilmiştir.

\section{Ambalaja sızıntı miktarı}

Örneklerde depolama boyunca vakum ambalaj içerisindeki sızıntının miktarı, 3., 7. ve 14. günlerde tartılan örnekler ile depolama başlangıcında tartılan örneklerin ağırlık farklarından yararlanılarak hesaplanmıştır.

\section{Istatistiksel değerlendirme}

Verilerin istatistiksel analizi SPSS 22.0 (IBM, ABD) paket programı kullanılarak \%95 güven aralığında gerçekleştirilmiştir. Tüm deneme gruplarına (dört farklı formülasyon) ait üretimler iki tekerrürlü olarak yürütülmüş (üretim tekrarı farklı günlerde gerçekleştirilmiştir), her bir tekerrüre ait analizler ise en az üç paralel olarak 
yapılmıştır. Çok değişkenli varyans analizi kullanılarak marine edilen tavuk göğüs etlerinde kalite parametrelerinin depolama süresi (D) ve antioksidan kullanım oranı (A) faktörleri bakımından farkıılığı incelenmiş, bu faktörlerin bir arada etkileşimleri $(D \times A)$ analiz edilmiş ve deneme grupları arasındaki anlamlı farklılıklar Post-hoc (Duncan) testi ile tanımlanmıştır.

\section{Araştırma Bulguları ve Tartışma}

\section{AE kullanımının MA ve STK üzerine etkisi}

Marine tavuk göğüs örneklerinde $A E$ kullanımının MA ve STK değerleri üzerine önemli etkisinin olduğu tespit edilmiştir $(p<0.05)$ (Çizelge 1). Örneklerin MA değerleri \%37.37-64.52, STK değerleri ise \%53.60-64.79 arasında değişiklik göstermiştir. \%0.5 oranında $A E$ kullanılan A-0.5 grubu, kontrol (A-0) grubuna benzer MA ve STK değerleri sergilemiştir. Buna rağmen $\% 0.75$ ve \%1 oranlarında $A E$ kullanılan $A-0.75$ ve $A-1$ grubu örneklerinde MA ve STK değerlerinin A-0 örneklerinden önemli düzeyde düşük olduğu kaydedilmiştir $\quad(p<0.05)$. Dolayısıyla, artan oranlarda AE kullanımının tavuk göğüs kaslarında hem marinasyon verimi hem de bünyede suyu tutma kabiliyetinin azalmasına yol açtığı görülmektedir. Benzer araştırmalarda, antioksidan karakterdeki ekstraktların kullanımının et dokusunu veya miyofibrilleri zayıflatarak suyun yapıdan uzaklaşmasını kolaylaştırdığı öne sürülmüştür (Iqbal ve ark., 2016; Malelak ve ark., 2017). Çalışma bulgularından farklı olarak, \%0.02 kekik, \%0.03 biberiye ve \%0.03 ardıç uçucu yağı karışımı ile marine edilen tavuk filetolarında başlangıçta marinasyon sıvısının daha yüksek miktarda absorbe edildiği görülmüş, depolama sırasında ise gruplar arası farklılık gözlenmemiştir (Siroli ve ark., 2020). Bu farklılığın nedeninin, marinasyon formülasyonunda kullanılmış olan diğer katkılar ve marinasyon yöntemi farklılığından kaynaklanmış olduğu düşünülmektedir.

Tartışılan bu noktalara ilaveten, örneklerin STK değerlerinde gözlenen azalmanın kullanılan ekstraktın marinatların $\mathrm{pH}$ değerini etkilemesinden kaynaklanabileceği de düşünülmektedir. Samples ve ark. (2010) tarafından gerçekleştirilen bir çalışmada, ringa balığı filetolarının mürver, kızılıı veya siyah frenk üzümü konsantre tozları ile marine edilmesi sonucunda kontrol gruplarına kıyasla daha düşük miktarda suyun tutulabildiği raporlanmıştır. Bir diğer çalışmada, tavuk göğüs filetolarının marinasyonunda üzüm çekirdeği ekstraktı kullanımı, benzer olarak STK değerlerinde önemli azalmaya neden olmuştur (Kang ve ark., 2017).

Çizelge 1. Ardıç ekstraktı kullanımının marine tavuk göğüslerin marinat absorbsiyonu (MA) ve su tutma kapasitesi (STK) üzerine etkisi

Table 1. The effect of juniper extract use on marination absorption (MA) and water holding capacity (WHC) of marinated chicken breasts

\begin{tabular}{|c|c|c|c|c|c|}
\hline \multirow[b]{3}{*}{ Varyans } & \multirow[b]{3}{*}{ Faktör } & \multirow{2}{*}{\multicolumn{2}{|c|}{$\begin{array}{l}\text { MA (\%) } \\
M A(\%)\end{array}$}} & \multirow{2}{*}{\multicolumn{2}{|c|}{$\begin{array}{l}\text { STK (\%) } \\
W H C(\%)\end{array}$}} \\
\hline & & & & & \\
\hline & & Ortalama & $P$ değeri & Ortalama & P değeri \\
\hline Kaynağı & Factor & 土standart sapma & (sig.) & 土standart sapma & (sig.) \\
\hline Variance & & Mean & $P$ value & Mean & $P$ value \\
\hline source & & 土standard deviation & (sig.) & 土standard deviation & (sig.) \\
\hline \multirow[t]{4}{*}{$A$} & 0 & $58.18^{a b} \pm 5.36$ & $0.000 *$ & $64.79^{a} \pm 0.93$ & $0.002 *$ \\
\hline & 0.5 & $64.52^{a} \pm 1.30$ & & $61.07^{a b} \pm 0.42$ & \\
\hline & 0.75 & $55.92^{b} \pm 5.49$ & & $59.60^{b} \pm 2.10$ & \\
\hline & 1 & $37.37^{c} \pm 0.52$ & & $53.60^{c} \pm 3.54$ & \\
\hline
\end{tabular}

a, b, c: Aynı sütundaki farklı harfler istatistiksel olarak önemli farklılıkları göstermektedir ( $\alpha=0.05$ seviyesinde).

*istatistiksel olarak önemli farklılık var.

A: Antioksidan oranı

Different superscripts in the same column indicate statistically significant differences ( $\alpha=0.05$ level).

* Statistically significant difference

A: Antioxidant rate 
AE kullanımının kimyasal kompozisyon üzerine etkisi

Farklı oranlarda $A E$ içeren marinasyon çözeltileri ile muamele edilen tavuk göğüs etlerinin kimyasal kompozisyonu Çizelge 2'de sunulmuştur. Örneklerin nem, yağ, protein ve kül değerlerinin sırasıyla \%74.98-76.31, \%1.49-2.39, \%19.69-20.56 ve \%1.61-2.22 aralığında olduğu kaydedilmiştir. AE kullanımının nem, yağ ve protein miktarları üzerine istatistiksel olarak anlamlı etkisi bulunmamıştır ( $p>0.05$ ). Yapılan bir çalışmada, manda etinin \%1.5 zencefil ekstraktı veya $\% 3$ limon suyu ile marine edilmesinin örneklerin nem değerlerini etkilemediği bildirilmiştir (Kassem ve ark., 2009). Ergezer
(2005) ise hem bazik hem de asidik marinasyon uygulamalarında kanatlı etlerinin nem ve kül miktarlarının artış gösterdiğini, protein miktarının azaldığını, ancak yağ miktarının önemli ölçüde değişmediğini bildirmiştir. Mevcut çalışmada, marinat formülasyonlarında kullanılan ekstrakt konsantrasyonunun oldukça düşük olmasından dolayı marine tavuk göğsü örneklerinde kimyasal kompozisyonun önemli düzeyde değişmediği görülmektedir. Bahsedilen çalışmalar incelendiğinde ise, ekstrakt kullanımından ziyade marinasyon çözeltisinin karakteristiklerinin kimyasal kompozisyon üzerinde daha etkili olduğu görülmektedir.

Çizelge 2. Ardıç ekstraktı kullanımının marine tavuk göğüslerin kimyasal kompozisyonu üzerine etkisi Table 2. The effect of using juniper extract on chemical composition of marinated chicken breasts

\begin{tabular}{|c|c|c|c|c|c|c|c|c|c|}
\hline \multirow[b]{2}{*}{$\begin{array}{c}\text { Varyans } \\
\text { Kaynağı } \\
\text { Variance } \\
\text { source }\end{array}$} & \multirow[b]{2}{*}{$\begin{array}{l}\text { Faktör } \\
\text { Factor }\end{array}$} & \multicolumn{2}{|c|}{$\begin{array}{c}\text { Nem (\%) } \\
\text { Moisture (\%) }\end{array}$} & \multicolumn{2}{|c|}{$\begin{array}{l}\text { Yağ (\%) } \\
\text { Fat (\%) }\end{array}$} & \multicolumn{2}{|c|}{$\begin{array}{l}\text { Protein (\%) } \\
\text { Protein (\%) }\end{array}$} & \multicolumn{2}{|c|}{$\begin{array}{l}\text { Kül (\%) } \\
\text { Ash (\%) }\end{array}$} \\
\hline & & $\begin{array}{c}\text { Ortalama } \\
\text { 土standart } \\
\text { sapma } \\
\text { Mean } \\
\pm \text { standard } \\
\text { deviation }\end{array}$ & $\begin{array}{l}\text { P değeri } \\
\text { (sig.) } \\
\text { P value } \\
\text { (sig.) }\end{array}$ & $\begin{array}{c}\text { Ortalama } \\
\text { 土standart } \\
\text { sapma } \\
\text { Mean } \\
\pm \text { standard } \\
\text { deviation }\end{array}$ & $\begin{array}{l}\text { P değeri } \\
\text { (sig.) } \\
\text { P value } \\
\text { (sig.) }\end{array}$ & $\begin{array}{c}\text { Ortalama } \\
\text { 土standart } \\
\text { sapma } \\
\text { Mean } \\
\pm \text { standard } \\
\text { deviation }\end{array}$ & $\begin{array}{l}\text { P değeri } \\
\text { (sig.) } \\
\text { P value } \\
\text { (sig.) }\end{array}$ & $\begin{array}{c}\text { Ortalama } \\
\pm \text { standart } \\
\text { sapma } \\
\text { Mean } \\
\pm \text { standard } \\
\text { deviation }\end{array}$ & $\begin{array}{l}\text { P değer } \\
\text { (sig.) } \\
\text { P value } \\
\text { (sig.) }\end{array}$ \\
\hline \multirow[t]{8}{*}{ A } & 0 & 74.98 & 0.512 & 2.29 & 0.522 & 20.51 & 0.843 & $2.22^{\mathrm{a}}$ & 0.007 \\
\hline & & \pm 1.81 & & \pm 0.15 & & \pm 1.65 & & \pm 0.06 & \\
\hline & 0.5 & 75.63 & & 2.23 & & 20.20 & & $1.94^{a}$ & \\
\hline & & \pm 0.73 & & \pm 1.54 & & \pm 2.00 & & \pm 0.21 & \\
\hline & 0.75 & 75.88 & & 1.49 & & 20.56 & & $2.07^{a}$ & \\
\hline & & \pm 0.17 & & \pm 0.12 & & \pm 0.13 & & \pm 0.11 & \\
\hline & 1 & 76.31 & & 2.39 & & 19.69 & & $1.61^{b}$ & \\
\hline & & \pm 0.79 & & \pm 0.31 & & \pm 0.54 & & \pm 0.18 & \\
\hline
\end{tabular}

a, b: Aynı sütundaki farklı harfler istatistiksel olarak önemli farklılıkları göstermektedir ( $\alpha=0.05$ seviyesinde).

A: Antioksidan oranı

Different superscripts in the same column indicate statistically significant differences ( $\alpha=0.05$ level).

A: Antioxidant rate

Depolama ve AE kullanımının pH üzerine etkisi

$A E$ ile marine edilen ve 14 gün boyunca depolanan tavuk göğüs etlerinde depolama süresi ve $A E$ kullanımının $\mathrm{pH}$ değerlerine etkisi Çizelge 3 'te, depolama boyunca $\mathrm{pH}$ değerlerinin gruplar arasındaki değişimi ise Şekil 2'de verilmiştir. Depolama süresi (D) ve antioksidan oranı (A) interaksiyonunun $(D \times A) \mathrm{pH}$ değerleri üzerinde önemli bir etkisinin olduğu görülmüştür $(p<0.05)$. Örneklerin depolama başlangıcındaki pH değerleri 6.00-6.25 arasında değişiklik göstermiş olup depolama boyunca $\mathrm{pH}$ değerlerinde genel olarak önemli azalmalar saptanmıştır $(p<0.05)$. Depolama başlangıcında A1 örneklerinin $\mathrm{pH}$ değerinin kontrol örneklerinin $\mathrm{pH}$ değerlerinden daha düşük olduğu gözlenmiştir $(p<0.05)$. Bu durumda marinasyon çözeltilerinde \%1 oranında $A E$ ilavesinin $\mathrm{pH}$ değerini düşürücü yönde bir etkiye neden olduğu görülmektedir. Benzer bir araştırmada, domuz filetolarının meyve ekstraktları ile marinasyonu sonucu $\mathrm{pH}$ değerleri kontrol grubundan daha düşük bulunmuştur (Kim ve ark., 2016). K ve A-0.5 gruplarında ise depolama boyunca benzer $\mathrm{pH}$ değerleri 
ölçülmüştür. Benzer şekilde, ördek etinin \%2.5, $\% 5$ ve \%7.5 oranlarında yeşil çay ekstraktı ile marinasyonunun ardından örneklerin $\mathrm{pH}$ değerleri arasında farklılık bulunmamıştır (Suradi ve ark., 2019). Bununla birlikte depolama süresince farklı AE oranları ile formüle edilen marine tavuk göğüs örneklerinde $\mathrm{pH}$ değerlerinin değişim seyrinin birbirinden farklı olduğu görülmektedir. Buna göre $K$ ve A-0.5 gruplarına ait örneklerde depolama sonunda ölçülen $\mathrm{pH}$ değerleri, başlangıç değerlerine göre önemli ölçüde azalma göstermiş $(p<0.05), A-0.75$ grubu örneklerinde depolama sonunda $\mathrm{pH}$ değerleri başlangıca kıyasla yükselmiş $(p<0.05), A-1$ grubu örneklerinde ise önemli düzeyde değişmemiştir. Dolayısıyla depolama süresince $\mathrm{pH}$ değerinin en stabil kaldığı örnekler, $\mathrm{AE}$ konsantrasyonunun en yüksek düzeyde kullanıldığı A-1 grubu örnekleridir.

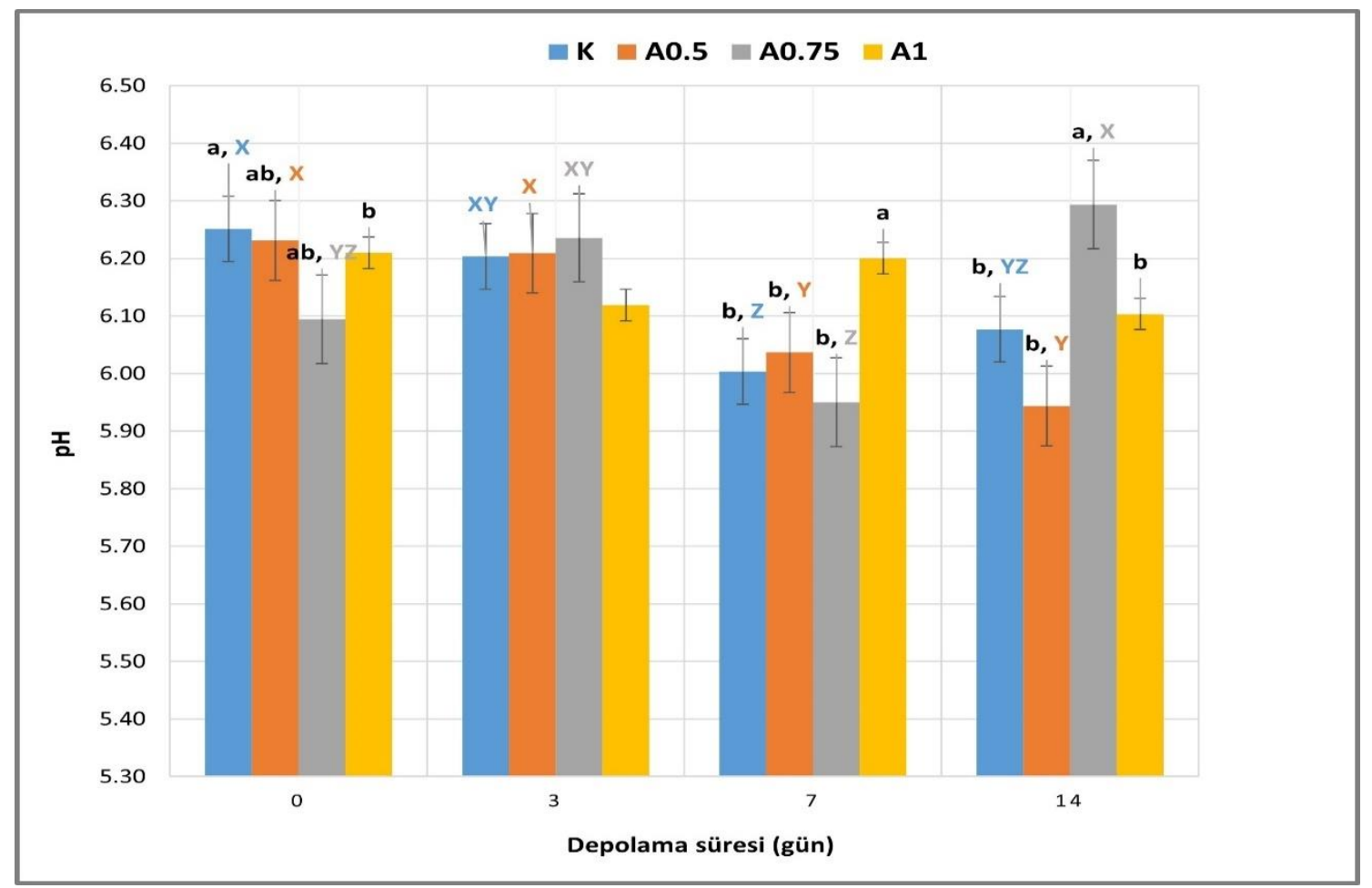

Şekil 2. Marine tavuk göğsü örneklerinin depolama boyunca pH değerleri

$\mathrm{K}$ : AE içermeyen kontrol grubu, A0.5: \%0.5 oranında AE içeren deneme grubu, $A 0.75: \% 0.75$ oranında $A E$ içeren deneme grubu, A1: \%1 oranında AE içeren deneme grubu. Veriler, standart hata çubukları ile birlikte sunulmuştur. $a, b, c:$ Aynı depolama gününde (farklı renkli sütunlar) gruplar arasındaki istatistiksel farkın önemli düzeyde olduğunu göstermektedir ( $\alpha=0.05$ seviyesinde). X, Y, Z: Aynı grup içerisinde (aynı renkli sütunlar) depolama süresi boyunca istatistiksel farkın önemli düzeyde olduğunu göstermektedir ( $\alpha=0.05$ seviyesinde).

Figure 2. $\mathrm{pH}$ values of marinated chicken breast samples during storage

K: Control group without AE, A0.5: The treatment that contained 0.5\% AE, A0.75: The treatment that contained 0.75\% AE, A1: The treatment that contained $1 \% A E$. The data were presented with standard error bars. $a, b, c:$ Indicates that the statistical difference is significant at the same storage day (the columns with different colors) within the treatments $(\alpha=0.05$ level). $X, Y, Z$ : Indicates that the statistical difference is significant within the same treatment (the columns with same colors) throughout storage ( $\alpha=0.05$ level). 
Çizelge 3. Ardıç ekstraktı ve depolama süresinin marine tavuk göğüslerin pH değeri üzerine etkisi

Table 3. The effects of juniper extract and storage time on $\mathrm{pH}$ value of marinated chicken breasts

\begin{tabular}{|c|c|c|c|c|}
\hline & & & $\begin{array}{l}\mathrm{pH} \\
\mathrm{pH}\end{array}$ & \\
\hline Varyans Kaynağı & Faktör & Ortalama & $\begin{array}{l}\text { Standart hata } \\
\text { Standard error }\end{array}$ & P değeri (sig.) \\
\hline Variance source & Factor & Mean & & $\begin{array}{c}\text { P value } \\
\text { (sig.) }\end{array}$ \\
\hline \multirow[t]{4}{*}{$\mathrm{D}$} & 0 & $6.20^{\mathrm{a}}$ & 0.023 & $0.000 *$ \\
\hline & 3 & $6.19^{a}$ & & \\
\hline & 7 & $6.05^{b}$ & & \\
\hline & 14 & $6.10^{b}$ & & \\
\hline \multirow[t]{4}{*}{ A } & 0 & 6.13 & 0.023 & 0.415 \\
\hline & 0.5 & 6.11 & & \\
\hline & 0.75 & 6.14 & & \\
\hline & 1 & 6.16 & & \\
\hline$D \times A$ & - & - & - & $0.000 *$ \\
\hline
\end{tabular}

a, b: Aynı sütundaki farklı harfler istatistiksel olarak önemli farklılıkları göstermektedir ( $\alpha=0.05$ seviyesinde).

*istatistiksel olarak önemli farklılık var.

A: Antioksidan oranı, D: Depolama süresi

Different superscripts in the same column indicate statistically significant differences ( $\alpha=0.05$ level).

* Statistically significant difference

A: Antioxidant rate, D: Storage time

Depolama ve AE kullanımının TBARS değeri üzerine etkisi

Farklı oranlarda AE eklenerek hazırlanan marine tavuk göğüs etlerinde depolama süresi ve AE kullanımının TBARS değerlerine etkisi Çizelge 4'te, gruplar arasındaki değişim ise Şekil 3'te gösterilmiştir. Örneklerin TBARS değerleri depolama süresi ile antioksidan kullanımından ve (D $x \quad A)$ interaksiyonundan önemli düzeyde etkilenmiştir $(p<0.05)$. Depolamanın başlangıcında örneklerin TBARS değerleri arasında önemli bir farklılık saptanmamıştır. Depolamanın 3. gününde gerçekleştirilen analizler sonucunda ise en düşük TBARS değerinin marinasyon çözeltisinde \%1 AE kullanılan örneklere (A-1) ait olduğu belirlenmiştir $(p<0.05)$. Dolayısıyla artan oranda AE kullanımının örneklerde oksidasyonu yavaşlatıcı bir etki gösterdiği bulgulanmıştır. TBARS değerlerinin daha düşük olmasının $A E$ kompozisyonunda yer alan antioksidan özellikteki bileşiklerden kaynaklandığı düşünülmektedir. Ünver Alçay ve ark. (2018), ardıç ekstraktında bulunan bileşiklerin $\alpha$-pinen, $\beta$-pinen, apigenin, sabinen, $\beta$-sitosterol, kampesterol, limonen, cupressuflavone, flavonoidler, lignanlar ve tanninler olduğunu bildirmişlerdir. Benzer şekilde, tavuk göğüs filetoları ile gerçekleştirilen bir marinasyon çalışmasında, kekik ve portakal yağı karışımı kullanımı hem taze ette hem de dondurularak depolama boyunca oksidasyon reaksiyonlarını yavaşlatmıştır (Rimini ve ark., 2014). Bir diğer çalışmada, ördek etinin \%5 ve \%10 oranlarında zencefil ekstraktı ile marinasyonu sonucu 72 saatlik depolamanın süresince kontrol grubunda oksidasyon reaksiyonlarının daha hızlı ilerlediği saptanmıştır (Suryanti ve ark., 2014).

Depolamanın 3. gününde gözlenen sonuçların aksine, depolamanın 7. gününden itibaren $\% 0.5$ oranında $A E$ içeren örneklerde (A-0.5) oksidasyon gelişiminin diğer örneklere kıyasla daha yavaş olduğu gözlenmiştir $(p<0.05)$. A-0.75 ve A-1 gruplarına ait örneklerde ise depolamanın 7. ve 14. günlerinde TBARS değerlerinin diğer grupların TBARS değerlerinden daha yüksek olduğu kaydedilmiştir $(p<0.05)$. Benzer bir çalışmada, $\% 1.5$ ve \%3 oranında defne yaprağı ile marine edilen dana etlerinin TBARS değerinin depolamanın 7. gününden itibaren artan defne yaprağı konsantrasyonu ile arttığı görülmüştür (Şeker ve ark., 2020). Üzüm çekirdeği ekstraktı (\%0.05, \%0.1, \%0.3 ve \%0.5) ile muamele edilen tavuk göğüs filetolarında depolamanın ilk üç gününde TBARS değerlerinin kontrol grubuna kıyasla daha düşük olması sağlanmış olmakla 
birlikte, depolamanın ilerleyen aşamalarında bu etki ortadan kalkmıştır (Kang ve ark., 2017). Dolayısıyla, artan oranlarda AE kullanımının TBARS değerlerinin azalması ve oksidasyon seyrinin yavaşlatılması konusunda depolamanın erken dönemlerinde daha etkili olduğu sonucuna varılmıştır.

Çizelge 4. Ardıç ekstraktı ve depolama süresinin marine tavuk göğüslerin TBARS değeri üzerine etkisi Table 4. The effects of juniper extract and storage time on TBARS value of marinated chicken breasts

\begin{tabular}{|c|c|c|c|c|}
\hline \multirow[b]{2}{*}{ Varyans Kaynağı } & \multirow[b]{2}{*}{ Faktör } & \multicolumn{3}{|c|}{$\begin{array}{l}\text { TBARS değeri (mg malonaldehit/kg) } \\
\text { TBARS value ( } \mathrm{mg} \text { malonaldehyde/ } \mathrm{kg} \text { ) }\end{array}$} \\
\hline & & Ortalama & Standart hata & P değeri (sig.) \\
\hline Variance source & Factor & Mean & Standard error & $P$ value (sig.) \\
\hline \multirow[t]{4}{*}{$\mathrm{D}$} & 0 & $0.20^{b}$ & 0.007 & $0.000 *$ \\
\hline & 3 & $0.05^{d}$ & & \\
\hline & 7 & $0.13^{c}$ & & \\
\hline & 14 & $0.34^{a}$ & & \\
\hline \multirow[t]{4}{*}{$A$} & 0 & $0.14^{c}$ & 0.016 & $0.000 *$ \\
\hline & 0.5 & $0.10^{d}$ & & \\
\hline & 0.75 & $0.21^{b}$ & & \\
\hline & 1 & $0.28^{a}$ & & \\
\hline
\end{tabular}

$D \times A$

$0.000^{*}$

a, b, c, d: Aynı sütundaki farklı harfler istatistiksel olarak önemli farklılıkları göstermektedir ( $\alpha=0.05$ seviyesinde). *istatistiksel olarak önemli farklılık var. A: Antioksidan oranı, D: Depolama süresi

Different superscripts in the same column indicate statistically significant differences ( $\alpha=0.05$ level).

*Statistically significant difference. A: Antioxidant rate, D: Storage time

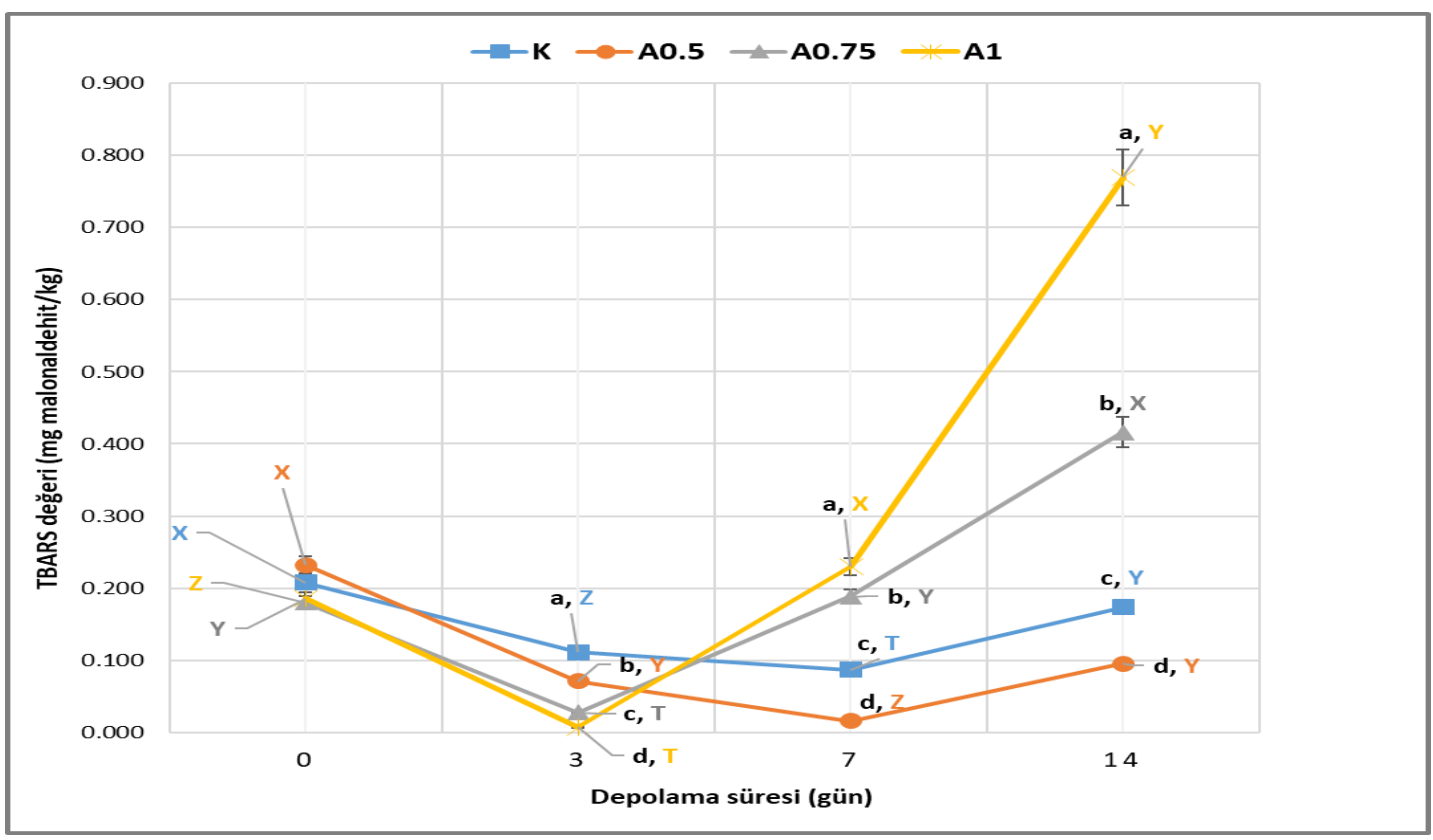

Şekil 3. Marine tavuk göğsü örneklerinin depolama boyunca TBARS değerleri

$\mathrm{K}$ : $\mathrm{AE}$ içermeyen kontrol grubu, A0.5: \%0.5 oranında $\mathrm{AE}$ içeren deneme grubu, $\mathrm{A0.75:} \% 0.75$ oranında $\mathrm{AE}$ içeren deneme grubu, A1: \%1 oranında AE içeren deneme grubu. Veriler, standart hata çubukları ile birlikte sunulmuştur.

a, b, c: Aynı depolama gününde (farklı renkli çizgiler) gruplar arasındaki istatistiksel farkın önemli düzeyde olduğunu göstermektedir ( $\alpha=0.05$ seviyesinde).

X, Y, Z: Aynı grup içerisinde (aynı renkli çizgiler) depolama süresi boyunca istatistiksel farkın önemli düzeyde olduğunu göstermektedir ( $\alpha=0.05$ seviyesinde).

Figure 3. TBARS values of marinated chicken breast samples during storage

K: Control group without $A E, A 0.5$ : The treatment that contained 0.5\% AE, A0.75: The treatment that contained 0.75\% AE, A1: The treatment that contained $1 \% A E$. The data were presented with standard error bars.

$a, b, c$ : Indicates that the statistical difference is significant at the same storage day (the lines with different colors) within the treatments ( $\alpha=0.05$ level).

$X, Y, Z$ : Indicates that the statistical difference is significant within the same treatment (the lines with same colors) throughout storage ( $\alpha=0.05$ level). 
Depolama süreci boyunca örneklerin TBARS değerlerinin aynı grup içindeki değişimi incelendiğinde, depolama süresi ilerledikçe tüm örneklerin TBARS değerlerinde önce azalma, ardından önemli düzeylerde artış olduğu tespit edilmiştir $(p<0.05)$. Depolama sırasında TBARS değerlerinde meydana gelen azalmalar, malonaldehitlerin polimerizasyon reaksiyonlarına veya aminoasit ve proteinlerle etkileşim göstermesi ile ilişkilendirilmektedir (Bhattacharya ve ark., 1988; Jamora ve Rhee, 2002). TBARS değerlerindeki artış ise ilerleyen depolama sürecinde birincil oksidasyon ürünleri olan hidroperoksitlerin, ikincil oksidasyon ürünleri olan malonaldehitlere dönüşümü ile açıklanabilmektedir (Huang ve ark., 2014). Mevcut çalışmada, marine tavuk göğüs eti örneklerinde en yüksek TBARS değeri depolama sonunda A-1 grubunda (0.69 mg malonaldehit/kg örnek) kaydedilmiş olmasına rağmen bu grupta dahi oksidasyon için kabul edilebilirlik sınır değeri olan $1 \mathrm{mg}$ malonaldehit/kg örnek değeri (Ockerman, 1985) aşılmamıştır.

\section{Depolama ve AE kullanımının renk üzerine etkisi}

Marine tavuk göğüs etlerinin renk parametreleri üzerine depolama süresi ve $A E$ kullanımının etkisi Çizelge 5 'te, renk parametrelerinin gruplar arasında depolama boyunca gösterdiği değişim ise Şekil 4'te verilmiştir. Depolama süresi ve antioksidan kullanım oranı varyans kaynaklarının tekil etkileri, örneklerin tüm renk parametreleri üzerine etkili bulunmuştur $(p<0.05)$. Bununla birlikte $D \times A$ varyans kaynağının göğüs etlerinin $L^{*}$ değerleri üzerine istatistiksel etkisi olmadığı görülmüştür ( $p>0.05)$. Depolamanın tekil etkisinin $L^{*}$ değeri üzerinde etkisi incelendiğinde, ilk üç depolama periyodu arasında farklılık bulunmamış olup ( $p>0.05), 14$. günde örneklerin aydınlık değerinin diğer günlere kıyasla daha yüksek olduğu gözlenmiştir $(p<0.05)$. Depolama sonunda örneklerin ambalaja sızıntı miktarının artışı sonucunda yüzeyde daha fazla su bulunduğu ve yüzeydeki bu suyun ışığın daha çok yansımasına neden olarak aydınlık değerlerini artırdığı düşünülmektedir. Ayrıca antioksidan kullanım miktarı arttıkça $L^{*}$ değerlerinin artması $(p<0.05)$, antioksidan kullanılan örneklerdeki düşük STK değerleri ile de ilişkilendirilebilir.

Göğüs etlerinin $a^{*}$ değerlerine AE kullanım oranının etkisi incelendiğinde, depolama başlangıcında en yüksek $a^{*}$ değerinin $\% 0.5$ oranında $A E$ kullanılan örneklerde kaydedildiği görülmektedir $(p<0.05)$. Diğer örneklerin $a^{*}$ değerleri ise depolama başlangıcında kontrol grubunun $a^{*}$ değerlerine benzerdir. Samples ve ark. (2020), mürver ve frenk üzümü konsantre tozları ile marine edilen ringa balığı filetolarında $a^{*}$ değerlerinin kontrol örneklerine göre daha düşük olduğunu raporlamıştır. Depolamanın sonunda kontrol örneklerinin $a^{*}$ değerleri başlangıca kıyasla önemli ölçüde düşmüş $(p<0.05)$, A-1 gruplarında ise depolama değerleri tüm periyotlarda stabil kalmıştır.

Depolama başlangıcında marine tavuk göğüs örneklerinde $\% 0.75$ ve $\% 1$ oranında AE kullanımı $b^{*}$ değerlerinin yükselmesine neden olmuş $(p<0.05) ; A-0$ ve A-0.5 örneklerinin $b^{*}$ değerleri arasında ise önemli bir farklılık tespit edilmemiştir. Dolayısıyla artan oranda $\mathrm{AE}$ kullanımının, ekstraktın karakteristik rengine bağı olarak sarılık değerini belirli bir konsantrasyonun üzerinde yükselttiği görülmektedir. Yapılan bir çalışmada, $\% 1$ ve $\% 3$ kerkede ekstraktı ile $\% 1$ ve \%2 misket limonu ilavesiyle marine edilen füme sığır eti örneklerinde $b^{*}$ değerleri düşmüş, misket limonu ekstraktı seviyesi \%3'e çıkarıldığında ise b* değerleri yükselmiştir (Malelak ve ark., 2017). Mevcut çalışmada depolamanın sarılık değerleri üzerine etkisi incelendiğinde, $A-0$ ve $A-0.75$ grupları örneklerinde 14 . gün ölçülen $b^{*}$ değerlerinin başlangıca kıyasla yükseldiği $(p<0.05), A-0.5$ ve A-1 grubu örneklerinde ise depolama başlangıcı ve sonunda ölçülen $b^{*}$ değerlerinin benzer olduğu bulunmuştur. 
Çizelge 5. Ardıç ekstraktı ve depolama süresinin marine tavuk göğüslerin renk parametreleri üzerine etkisi

Table 5. The effects of juniper extract and storage time on color parameters of marinated chicken breasts

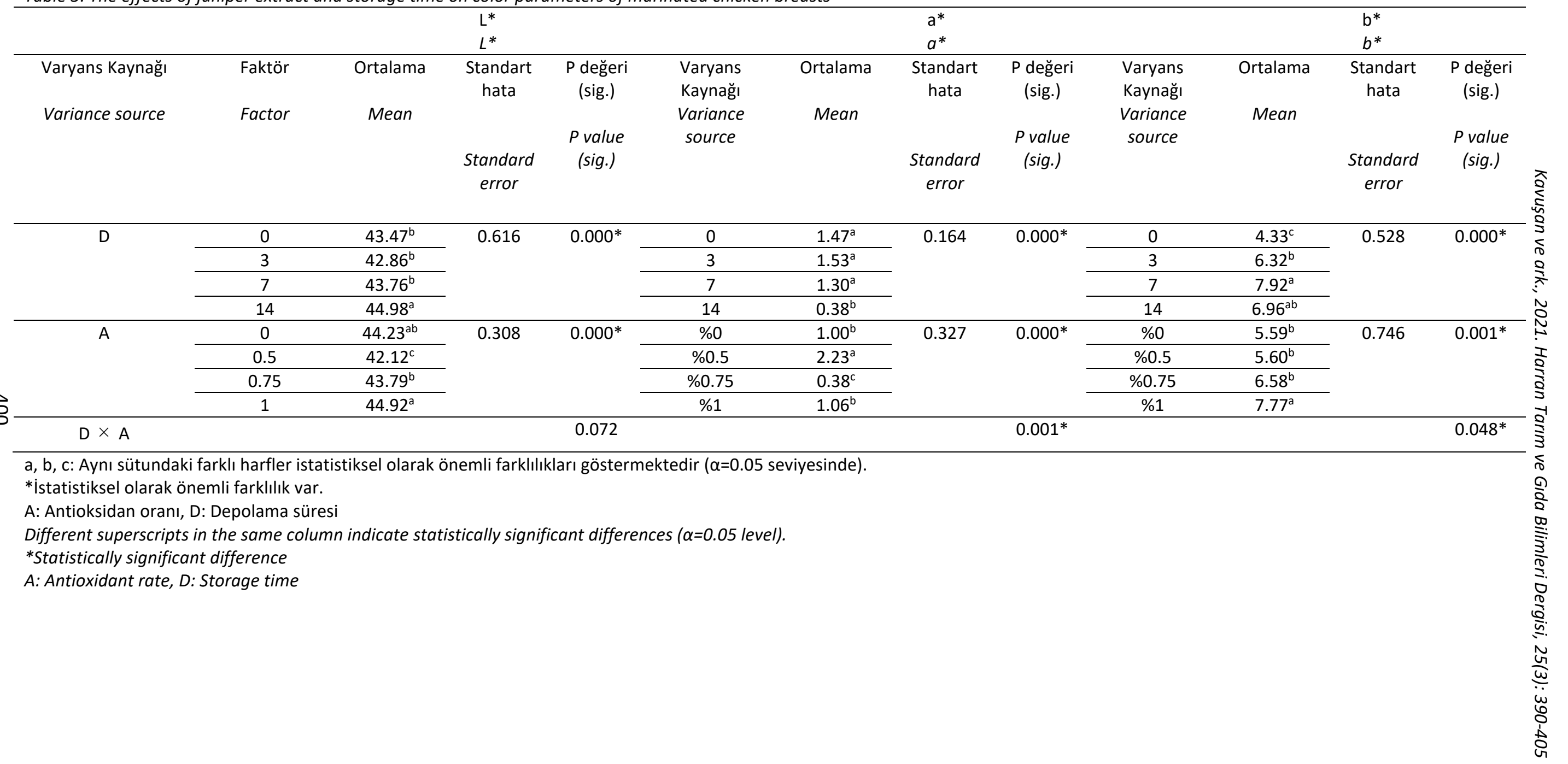



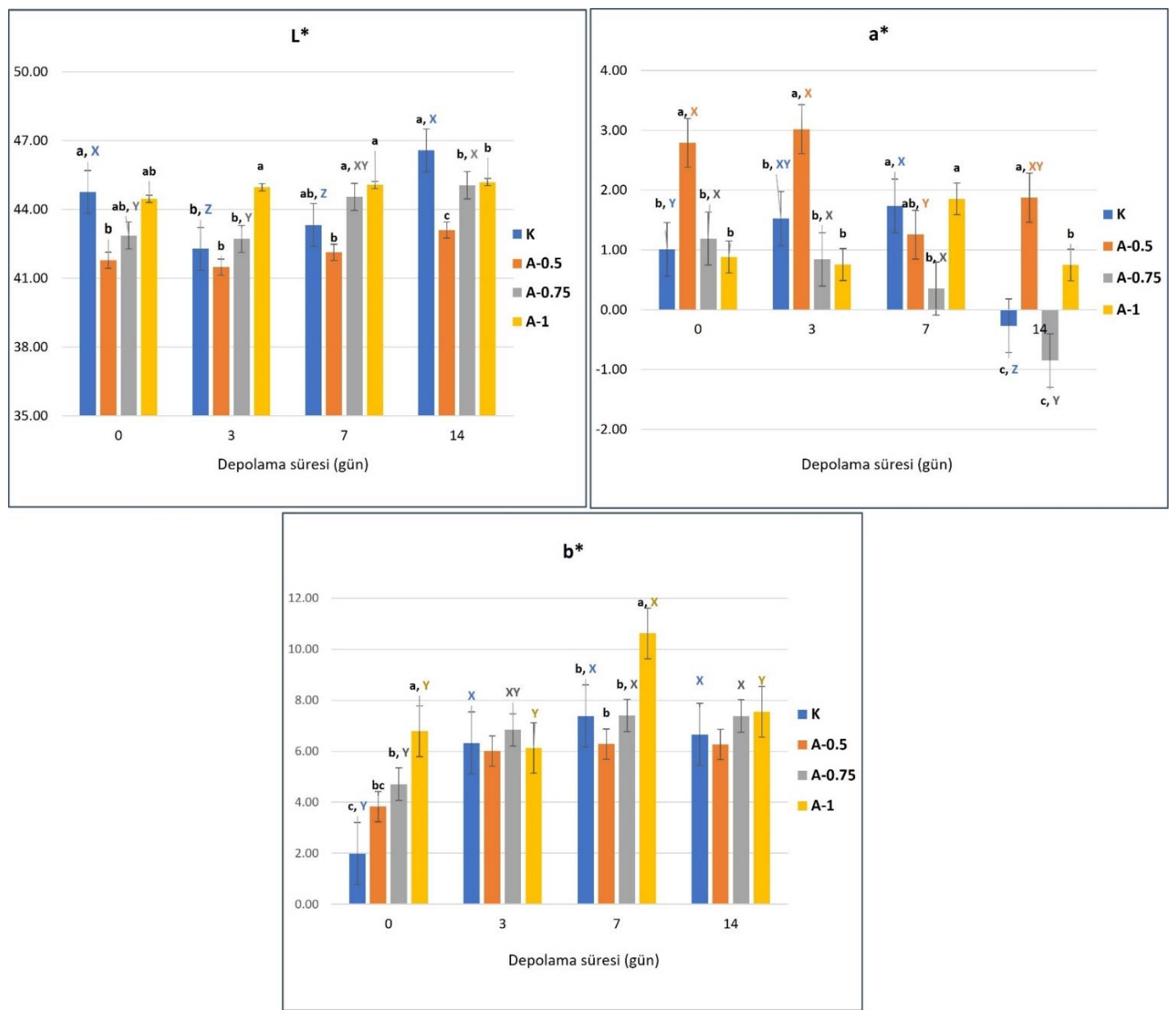

Şekil 4. Marine tavuk göğsü örneklerinin depolama boyunca renk $\left(L^{*}, a^{*}, b^{*}\right)$ parametreleri

K: AE içermeyen kontrol grubu, A0.5: \%0.5 oranında AE içeren deneme grubu, A0.75: \%0.75 oranında AE içeren deneme grubu, A1: \%1 oranında AE içeren deneme grubu. Veriler, standart hata çubukları ile birlikte sunulmuştur. a, b, c: Aynı depolama gününde (farklı renkli sütunlar) gruplar arasındaki istatistiksel farkın önemli düzeyde olduğunu göstermektedir ( $\alpha=0.05$ seviyesinde). X, Y, Z: Aynı grup içerisinde (aynı renkli sütunlar) depolama süresi boyunca istatistiksel farkın önemli düzeyde olduğunu göstermektedir ( $\alpha=0.05$ seviyesinde).

Figure 4. Color $\left(L^{*}, a^{*}, b^{*}\right)$ parameters of marinated chicken breast samples during storage

K: Control group without $A E, A 0.5$ : The treatment that contained 0.5\% AE, A0.75: The treatment that contained 0.75\% AE, A1: The treatment that contained $1 \% A E$. The data were presented with standard error bars. $a, b, c$ : Indicates that the statistical difference is significant at the same storage day (the columns with different colors) within the treatments $(\alpha=0.05$ level).

$X, Y, Z$ : Indicates that the statistical difference is significant within the same treatment (the columns with same colors) throughout storage ( $\alpha=0.05$ level).

\section{Depolama ve AE kullanımının ambalaja sızıntı} miktarı üzerine etkisi

Farklı oranlarda $A E$ ile marine edilen tavuk göğüs etlerinde depolama süresi ve $A E$ kullanımının ambalaja sızıntı miktarına etkisi Çizelge 6'da, depolama boyunca gruplar arasındaki değişim ise Şekil 5'te sunulmuştur. Depolama süresinin uzaması; vakum ambalaj içerisinde biriken sıvı miktarının artışına bağlı olarak ambalaja sızıntı miktarının artmasına neden olmuştur ( $p<0.05$ ) (Çizelge 6$)$. Antioksidan kullanım oranının tekil etkisi yalnızca \%1 $\mathrm{AE}$ kullanılan örneklerde göze çarpmaktadır. Depolama süresi ve antioksidan kullanım oranının interaksiyonu ise ambalaja sızıntı değerleri üzerine etkili bulunmamıştır $(p>0.05)$. Tüm deneme gruplarında depolama süresinin sonunda ambalaja sızıntı miktarının, erken depolama günlerine kıyasla önemli düzeyde yüksek olduğu görülmektedir $(p<0.05)$ Depolama süresi 
sonunda A-1 grubu örneklerinde diğer gruplara ait örneklere kıyasla daha yüksek olan ambalaja sızıntı miktarının bu örneklerin düşük marinasyon verimine bağlı olduğu düşünülmektedir.

Çizelge 6. Ardıç ekstraktı ve depolama süresinin ambalaja sızıntı miktarı üzerine etkisi

Table 6. The effects of juniper extract and storage time on purge loss

\begin{tabular}{|c|c|c|c|c|}
\hline \multirow{3}{*}{$\begin{array}{l}\text { Varyans Kaynağı } \\
\text { Variance source }\end{array}$} & \multirow{3}{*}{ Faktör } & \multicolumn{3}{|c|}{$\begin{array}{c}\text { Ambalaja sızıntı miktarı (\%) } \\
\text { Purge loss (\%) }\end{array}$} \\
\hline & & Ortalama & Standart hata & P değeri (sig.) \\
\hline & & & Standard error & P value (sig.) \\
\hline & Factor & Mean & & \\
\hline \multirow[t]{3}{*}{$D$} & 3 & $0.97^{c}$ & 0.276 & $0.000 *$ \\
\hline & 7 & $3.53^{b}$ & & \\
\hline & 14 & $4.30^{a}$ & & \\
\hline \multirow[t]{4}{*}{ A } & 0 & $2.56^{\mathrm{b}}$ & 0.712 & $0.025^{*}$ \\
\hline & 0.5 & $2.61^{b}$ & & \\
\hline & 0.75 & $2.68^{b}$ & & \\
\hline & 1 & $3.89^{a}$ & & \\
\hline
\end{tabular}

$\mathrm{D} X \mathrm{~A}$

0.082

a, b, c: Aynı sütundaki farklı harfler istatistiksel olarak önemli farklılıkları göstermektedir ( $\alpha=0.05$ seviyesinde). $*$ istatistiksel olarak önemli farklılık var. A: Antioksidan oranı, D: Depolama süresi

Different superscripts in the same column indicate statistically significant differences ( $\alpha=0.05$ level).

* Statistically significant difference. A: Antioxidant rate, D: Storage time



Şekil 5. Marine tavuk göğsü örneklerinin depolama boyunca ambalaja sızıntı miktarı (\%)

$\mathrm{K}$ : $\mathrm{AE}$ içermeyen kontrol grubu, A0.5: \%0.5 oranında AE içeren deneme grubu, A0.75: \%0.75 oranında $A E$ içeren deneme grubu, A1: \%1 oranında AE içeren deneme grubu. Veriler, standart hata çubukları ile birlikte sunulmuştur. a, b, c: Aynı depolama gününde (farklı renkli çizgiler) gruplar arasındaki istatistiksel farkın önemli düzeyde olduğunu göstermektedir ( $\alpha=0.05$ seviyesinde). X, Y, Z: Aynı grup içerisinde (aynı renkli çizgiler) depolama süresi boyunca istatistiksel farkın önemli düzeyde olduğunu göstermektedir ( $\alpha=0.05$ seviyesinde).

Figure 5. Purge loss of marinated chicken breast samples during storage

K: Control group without $A E, A 0.5$ : The treatment that contained 0.5\% AE, A0.75: The treatment that contained 0.75\% AE, A1: The treatment that contained $1 \%$ AE. The data were presented with standard error bars. $a, b, c:$ Indicates that the statistical difference is significant at the same storage day (the lines with different colors) within the treatments ( $\alpha=0.05$ level). $X, Y, Z$ : Indicates that the statistical difference is significant within the same treatment (the lines with same colors) throughout storage ( $\alpha=0.05$ level). 


\section{Sonuçlar}

$\mathrm{Bu}$ çalışmanın sonucunda, marinasyon formülasyonunda $\% 0.5$ oranında $\mathrm{AE}$ bulunan tavuk göğüs etlerinde teknolojik özellikler, kimyasal kompozisyon ve renk üzerinde olumsuz etkilere yol açmadan lipit oksidasyon reaksiyonlarının önemli ölçüde yavaşlatıldığı tespit edilmiştir. ileride gerçekleştirilecek çalışmalarda, önemli bir potansiyeli bulunan ardıç bileşenlerinin farklı et ürünü formülasyonlarında da kullanım olanaklarının araştırılması, bu konuda ürünlerin daha uzun süreli soğutularak veya dondurularak depolama sürecinde oksidatif ve duyusal kalitenin takibi konusundaki araştırmaların sürdürülmesi önerilmektedir.

\section{Ekler}

Çalışmanın gerçekleştirilmesi aşamasında üretimde ve analizler çalışmalarında verdikleri destekten dolayı Ege Üniversitesi Gıda Mühendisliği Bölümü lisans öğrencileri Nilsu ÇETINALP ve Esra PARLAKÇI' ya teşekkür ederiz.

Çıkar Çatışması Beyanı: Makale yazarları, aralarında herhangi bir çıkar çatışması olmadığını beyan ederler.

Yazar Katkısı: Hülya Serpil KAVUŞAN, çalışma üretimi ve analizlerinin gerçekleştirilmesi, veri analizi, raporlama ve yazım; Burcu ÖzTÜRK KERIMOĞLU, çalışma tasarımı, deneme deseninin oluşturulması, üretim çalışmalarının gerçekleştirilmesi, veri analizi, makale yazım ve redaksiyonu; Elnaz SHAREFIABADi, çalışma analizlerinin gerçekleştirilmesi; MELTEM SERDAROĞLU, çalışma tasarımı, deneme deseninin oluşturulması, çalışmanın yürütülmesi, verilerin değerlendirilmesi ve makale redaksiyonu konularında katkı sağlamıştır.

\section{Kaynaklar}

Alvarado, C., \& McKee, S. (2007). Marination to improve functional properties and safety of poultry meat. Journal of Applied Poultry Research, 16(1):
113-120.

https://doi.org/10.1093/japr/16.1.113.

Amaral, A. B., Silva, M. V. D., \& Lannes, S. C. D. S. (2018). Lipid oxidation in meat: mechanisms and protective factors-a review. Food Science and Technology, 38, 1-15. DOI: http://dx.doi.org/10.1590/fst.32518

AOAC. (2012). Official Methods of Analysis. 19th ed. Gaithersburg, MD, USA.

Banerjee, R., Verma, A. K., Das, A. K., Rajkumar, V., Shewalkar, A. A., \& Narkhede, H. P. (2012). Antioxidant effects of broccoli powder extract in goat meat nuggets. Meat Science, 91(2), 179-184. DOI: https://doi.org/10.1016/j.meatsci.2012.01.016

Bhattacharya, M., Hanna, M. A., \& Mandigo, R. W. (1988). Lipid oxidation in ground beef patties as affected by time-temperature and product packaging parameters. Journal of Food Science, 53(3), 714-717. DOI: https://doi.org/10.1111/j.13652621.1988.tb08938.x

Brenes, A., \& Roura, E. (2010). Essential oils in poultry nutrition: Main effects and modes of action. Animal Feed Science and Technology, 158(1-2), 1-14. DOI: https://doi.org/10.1016/j.anifeedsci.2010.03.007

Candan, T., \& Bağdatlı, A. (2017). Use of natural antioxidants in poultry meat. Celal Bayar Üniversitesi Fen Bilimleri Dergisi, 13(2), 279-291. DOI: https://doi.org/10.18466/CBAYARFBE.319752

Cho, H. S., Park, W., Hong, G. E., Kim, J. H., Ju, M. G., \& Lee, C. H. (2015). Antioxidant activity of Allium hookeri root extract and its effect on lipid stability of sulfurfed pork patties. Korean Journal for Food Science of Animal Resources, 35(1), 41-49. DOI: https://doi.org/10.5851/kosfa.2015.35.1.41

Çelik, Ş., Doğru, E., Yakar, Y., \& Ünver, N. (2021). Zeytin yaprağı ilavesinin zeytinyağının bazı karakteristik özelliklerine etkisi. Harran Tarım ve Gıda Bilimleri Dergisi, 25(1), 72-85. DOI: 10.29050/harranziraat.744568

Coşkun, i. (2019). Ardıç meyvesinden elde edilen uçucu yağda biyolojik aktivite araştırmaları, Yüksek Lisans Tezi, Ege Üniversitesi, Sağlık Bilimleri Enstitüsü, İzmir.

De Smet, S. (2012). Meat, poultry, and fish composition: Strategies for optimizing human intake of essential nutrients. Animal Frontiers, 2(4), 10-16. DOI: https://doi.org/10.2527/af.2012-0057

Dolatabadi, J. E. N., \& Kashanian, S. (2010). A review on DNA interaction with synthetic phenolic food additives. Food Research International, 43(5), 12231230.

DOI: https://doi.org/10.1016/j.foodres.2010.03.026.

Elmastaş, M., Gülçin, İ., Beydemir, Ş., İrfan Küfrevioğlu, Ö., \& Aboul-Enein, H. Y. (2006). A study on the in vitro antioxidant activity of juniper (Juniperus communis L.) fruit extracts. Analytical Letters, 39(1), 47-65. DOI: https://doi.org/10.1080/00032710500423385

Ergezer, H. (2005). Değişik yöntemlerle marine edilmiş kanatlı etlerinin kimyasal, mikrobiyolojik, tekstürel ve duyusal özellikleri, Yüksek Lisans Tezi, Pamukkale Üniversitesi, Fen Bilimleri Enstitüsü, Denizli.

Ergezer, H., \& Gökçe, R. (2004). Kanatli etlerinin marinasyon tekniği ile işlenmesi. Pamukkale Üniversitesi Mühendislik Bilimleri Dergisi, 10(2), 227-233.

Fadıloğlu, E. E., \& Serdaroğlu, M. (2018). Effects of pre and 
post-rigor marinade injection on some quality parameters of longissimus dorsi muscles. Korean Journal for Food Science of Animal Resources, 38(2), 325337.

DOI:

https://doi.org/10.5851/kosfa.2018.38.2.325

Falowo, A. B., Fayemi, P. O., \& Muchenje, V. (2014). Natural antioxidants against lipid-protein oxidative deterioration in meat and meat products: A review. Food Research International, 64, 171-181. DOI: https://doi.org/10.1016/j.foodres.2014.06.022

Flynn, A. W., \& Bramblett, V. D. (1975). Effects of frozen storage, cooking method and muscle quality on attributes of pork loins. Journal of Food Science, 40(3), 631-633.

DOI:

https://doi.org/10.1111/j.13652621.1975.tb12544.x

Gamage, H. G. C. L., Mutucumarana, R. K., \& Andrew, M. S. (2017). Effect of marination method and holding time on physicochemical and sensory characteristics of broiler meat. The Journal of Agricultural Sciences, 12, 172-184. DOI: http://doi.org/10.4038/jas.v12i3.8264

Gómez-Salazar, J. A., Ochoa-Montes, D. A., Cerón-García, A., Ozuna, C., \& Sosa-Morales, M. E. (2018). Effect of acid marination assisted by power ultrasound on the quality of rabbit meat. Journal of Food Quality, 5754930,

DOI: https://doi.org/10.1155/2018/5754930

Hafez, A. M. A. T. A., \& Eissawy, M. M. (2018). Effect of banana peel extract on sensory and bacteriological quality of marinated beef. Archives of Nutrition and Public Health, 1(1), 1-11.

Huang, Y., Li, H., Huang, T., Li, F., \& Sun, J. (2014). Lipolysis and lipid oxidation during processing of Chinese traditional smoke-cured bacon. Food Chemistry, 149, 31-39. DOI: https://doi.org/10.1016/j.foodchem.2013.10.081

Hughes, E., Cofrades, S., \& Troy, D. J. (1997). Effects of fat level, oat fibre and carrageenan on frankfurters formulated with 5, 12 and $30 \%$ fat. Meat Science, 45(3), 273-281. DOI: https://doi.org/10.1016/S0309-1740(96)00109-X

Inci, H., Ozdemir, G., Sengul, A. Y., Sogut, B., Nursoy, H., \& Sengul, T. (2016). Using juniper berry (Juniperus communis) as a supplement in Japanese quail diets. Revista Brasileira de Zootecnia, 45(5), 230-235. DOI: $\quad$ https://doi.org/10.1590/S180692902016000500004

Iqbal, S., Neelam, A., Alamgir, A., \& Nawaz, S. (2016). In vitro effects of papaya (Carica papaya), lemon juice (Citrus aurantifolia), vinegar and yogurt as a meat tenderizer. Journal of Chemical, Biological and Physical Sciences (JCBPS), 6(2), 568-573.

Ismail, M. A., Ibrahim, M. A., \& Ismail-Fitry, M. R. (2018). Application of Ziziphus Jujube (Red Date), Camellia Sinensis (Black Tea) and Aleurites Moluccana (Candle Nut) marinades as beef meat tenderizer. International Journal of Engineering \& Technology, 7(4.14), 307-311.

Jamora, J. J., \& Rhee, K. S. (2002). Storage stability of extruded products from blends of meat and nonmeat ingredients: Evaluation methods and antioxidative effects of onion, carrot, and oat ingredients. Journal of Food Science, 67(5), 16541659. DOI: https://doi.org/10.1111/j.13652621.2002.tb08700.x

Jeong, H., Lee, S., \& Han, G. D. (2020). The effect of s igumjang (Korean fermented barley bran) marination on the physicochemical properties of pork loin. Food Science and Biotechnology, 1-5. DOI: https://doi.org/10.1007/s10068-020-00767-x

Kang, S. T., Son, H. K., Lee, H. J., Choi, J. S., Choi, Y. I., \& Lee, J. J. (2017). Effects of grapefruit seed extract on oxidative stability and quality properties of cured chicken breast. Korean journal for food science of animal resources, 37(3), 429-439. DOI: https://doi.org/10.5851/kosfa.2017.37.3.429

Karam, L., Roustom, R., Abiad, M. G., El-Obeid, T., \& Savvaidis, I. N. (2019). Combined effects of thymol, carvacrol and packaging on the shelf-life of marinated chicken. International Journal of Food Microbiology, 291, 42-47. DOI: https://doi.org/10.1016/j.ijfoodmicro.2018.11.008

Kassem, G. M., Zahran, D. A., \& Ali, F. H. (2009). Efficacy of different marinades on tenderness and overall quality of buffalo meat. Assiut Veterinary Medical Journal, 55(121), 110-125.

Kim, H., Kim, D., Kim, H. J., Kim, H. J., \& Jang, A. (2016). Effect of marinating with fruits extracts on the quality and anti-oxidative peptide of pork loin. $62^{\text {nd }}$ International Congress of Meat Science and Technology, 14-19th August 2016, Bangkok, Thailand.

Malelak, G. E. M., Lalel, H. J. D., Kale, P. R., \& Jelantik, I. G. N. (2017). The Sensory Properties, Color, Microbial, Lipid Oxidation, and Residual Nitrite of Se'i Marinated with Lime and Roselle Calyces Extracts. Media Peternakan, 40(3), 194-201. DOI: https://doi.org/10.5398/medpet.2017.40.3.194

Mira-Sánchez, M. D., Castillo-Sánchez, J., \& Morillas-Ruiz, J. M. (2020). Comparative study of rosemary extracts and several synthetic and natural food antioxidants. Relevance of carnosic acid/carnosol ratio. Food Chemistry, 309, $125688 . \quad$ DOI: https://doi.org/10.1016/j.foodchem.2019.125688

Munekata, P. E. S., Rocchetti, G., Pateiro, M., Lucini, L., Domínguez, R., \& Lorenzo, J. M. (2020). Addition of plant extracts to meat and meat products to extend shelf-life and health-promoting attributes: An overview. Current Opinion in Food Science, 31, 81-87. DOI: https://doi.org/10.1016/j.cofs.2020.03.003

Ockerman, H. W. (1985). Quality control of post-mortem muscle tissue. Ohio State University; Columbus, Ohio, $\mathrm{OH}$, USA.

OECD/FAO. (2016). OECD-FAO Agricultural Outlook 2016-2025, OECD Publishing, Paris. Retrieved from: http://www.fao.org/3/15778E/I5778E.pdf

Ramli, A. N. M., Manap, N. W. A., Bhuyar, P., \& Azelee, N. I. W. (2020). Passion fruit (Passiflora edulis) peel powder extract and its application towards antibacterial and antioxidant activity on the preserved meat products. SN Applied Sciences, 2(10), 1-11. DOI: https://doi.org/10.1007/s42452-02003550-z

Rimini, S., Petracci, M., \& Smith, D. P. (2014). The use of thyme and orange essential oils blend to improve 
quality traits of marinated chicken meat. Poultry Science, 93(8), 2096-2102. DOI: https://doi.org/10.3382/ps.2013-03601

Sampels, S., Åsli, M., Vogt, G., \& Mørkøre, T. (2010). Berry marinades enhance oxidative stability of herring fillets. Journal of Agricultural and Food Chemistry, 58(23), 12230-12237. DOI: https://doi/10.1021/jf1017862

Singh, P., Yadav, S., Pathera, A., \& Sharma, D. (2020). Effect of vacuum tumbling and red beetroot juice incorporation on quality characteristics of marinated chicken breast and leg meats. Nutrition \& Food Science, 50(1), 143-155. DOI: https://doi.org/10.1108/NFS-03-2019-0079

Siroli, L., Baldi, G., Soglia, F., Bukvicki, D., Patrignani, F., Petracci, M., \& Lanciotti, R. (2020). Use of essential oils to increase the safety and the quality of marinated pork loin. Foods, 9(8), 987. DOI: https://doi.org/10.3390/foods9080987

Suradi, K., Gumilar, J., Ladyani, G. M. L., \& Putri, N. S. W. (2019). The effect of duck meat marination with various concentrations of green tea extract (Camellia sinensis) on physical, microbiological and acceptability properties. Scientific Papers-Animal Science Series: Lucrări Ştiinţifice - Seria Zootehnie, 72, 137-142.

Suryanti, U., Bintoro, V. P., Atmomarsono, U., Pramono, Y. B., \& Legowo, A. M. (2014). Antioxidant activity of Indonesian endogenous duck meat marinated in ginger (Zingiber officinale Roscoe) extract. International Journal of Poultry Science, 13(2), 102-107. DOI: https://doi.org/10.3923/ijps.2014.102.107
Şeker, i. T., Hastaoğlu, E., \& Saraç, M. G. (2020). Farklı aromatik bitkilerle marine edilip vakumlanarak saklanan dana etlerinin bazı özelliklerinin incelenmesi. Türk Turizm Araştırmaları Dergisi, 4(3), 2087-2101. DOI: 10.26677/TR1010.2020.468

Topçu, G., Erenler, R., Çakmak, O., Johansson, C. B., Çelik, C., Chai, H. B., \& Pezzuto, J. M. (1999). Diterpenes from the berries of Juniperus excelsa. Phytochemistry, 50(7), 1195-1199. DOI: https://doi.org/10.1016/S0031-9422(98)00675-X

Ünver Alçay, A., Akgül, C., Badayman, M., Dinçel, E. (2018). Ardıç meyve ve yağının kullanım alanları. Aydın Gastronomy, 2(2), 45-60. DOI: https://dergipark.org.tr/en/pub/aydingas/issue/390 $37 / 457638$

Vasilijević, B., Knežević-Vukčević, J., Mitić-Ćulafić, D., Orčić, D., Francišković, M., Srdic-Rajic, T., Jovanovic, M., \& Nikolić, B. (2018). Chemical characterization, antioxidant, genotoxic and in vitro cytotoxic activity assessment of Juniperus communis var. saxatilis. Food and Chemical Toxicology, 112, 118125. DOI: https://doi.org/10.1016/j.fct.2017.12.044

Witte, V. C., Krause, G. F., \& Bailey, M. E. (1970). A new extraction method for determining 2-thiobarbituric acid values of pork and beef during storage. Journal of Food Science, 35(5), 582-585. DOI: https://doi.org/10.1111/j.13652621.1970.tb04815.x

Xiong, G., Fu, X., Pan, D., Qi, J., Xu, X., \& Jiang, X. (2020). Influence of ultrasound-assisted sodium bicarbonate marination on the curing efficiency of chicken breast meat. Ultrasonics Sonochemistry, 60, 104808. DOI: https://doi.org/10.1016/j.ultsonch.2019.104808 